\title{
The Relevance of Shopper Marketing Touchpoints: An Empirical Study on Wine Choice in Restaurants
}

Submitted $3 / 12 / 18,1^{\text {st }}$ revision $13 / 1 / 19,2^{\text {nd }}$ revision $1 / 2 / 19$, accepted $13 / 2 / 19$

\author{
Paulo Duarte Silveira ${ }^{1 *}$
}

\begin{abstract}
:
Shopper marketing is a relatively new approach that calls for an examination of potential influences that can be triggered in several touchpoints along the entire path-to-purchase customers' journey.
\end{abstract}

The present study is carried out on that context, aiming to understand if the attributes considered by wine customers in restaurants are influenced by a touchpoint. For that purpose, an empirical quantitative study was conducted, with face-to-face interviews in restaurants to a target population of 663 wine customers.

Results show that most attributes with highest importance-levels ("wine color"; "wine region"; "certified wine region") were positively influenced by only one touchpoint related to previous consumption experience.

The attribute "brand" was influenced by several touchpoints, evidencing that managers should not aim to simplify the shopper marketing management by acting only on few touchpoints.

Keywords: Shopper marketing; Path to purchase; Wine marketing, Restaurants

JEL Classification: M31, L81, M37.

Acknowledgements: Author is grateful and acknowledge the cooperation of the students on interviews, as well as the shoppers interviewed and the restaurant owners.

Paper published with the funding support of Polytechnic Institute of Setúbal.

${ }^{1}$ College of Business Administration-Polytechnic Institute of Setúbal, Setúbal, Portugal, and CEFAGE-UE, Évora, Portugal. Corresponding author email: paulo.silveira@esce.ips.pt 


\section{Introduction}

Over the past twenty years there have been significant macro-changes (knowledge changes, lifestyle changes, technological changes and economical changes) that altered shopping patterns and buying decisions, presenting new challenges for retailers and manufacturers (Lee et al., 2017). The shopper marketing approach is a relatively new approach, but already proven and effective that is has been attracting retailers and suppliers attention and resources (Bogetić \& Stojković, 2015), fitting in those new challenges for retailers and manufacturers (Pinto et al., 2017), rooted in marketing theory as a manifestation of the place policy in the traditional marketing mix (Pinto et al., 2017).

Previous research on shopper marketing has been clearly focused on supermarkets, but the shopper marketing principles can also be useful to other types of retailers and producers (Gavilan et al., 2014; Ailawadi et al., 2009), such as the players in the wine industry (Pomarici et al., 2012). The present study aims to contribute to this research stream, by examining the influence of in-store and out-of-store shopper touchpoints on wine choice decision-making in restaurants. The research option to conduct an empirical study on restaurants (included in the Ho.Re.Ca system) is because wine sales in Ho.Re.Ca have been decreasing in most countries and, therefore, wine producers need to rethink the actions that can be undertaken to improve the sales and quality of wine supply in HoRe.Ca system (Hildebrandt, 2012; Pomarici et al., 2012). Moreover, retail wine purchasing is an important subject in wine academic research (Barber, 2012; Mueller et al., 2010a; Mueller et al., 2010b; Ritchie et al., 2010; Lockshin \& Knott, 2009; Casini et al., 2009; Quinton and Harridge-March, 2008; Hollebeek et al., 2007, Lockshin et al., 2006; Orth \& Bourrain, 2005), since the purchasing behaviour is affected by a range of different factors, which lead to differences in the way customers approach wines (Lockshin \& Corsi, 2012). Previous research on wine purchasing has been focused on wine stores (Stening \& Lockshin, 2001; Lockshin \& Kahrimanis, 1998) and supermarkets (Handley \& Lockshin, 1997), but restaurants are also an important outlet, yet less studied (Jaeger et al., 2010; 2009; Cohen et al., 2009; Preszler \& Schmit, 2009).

\section{Conceptual Background}

\subsection{Shopper marketing approach and shopper touchpoints}

Shopper marketing is "the planning and execution of all marketing activities that influence a shopper along, and beyond, the entire path-to-purchase, from the point at which the motivation to shop first emerges through purchase, consumption, repurchase, and recommendation" (Shankar et al., 2011, p. 29). Shopper marketing is not opposed to traditional marketing, on the contrary, is compatible with traditional marketing tools (Ziliani \& Ieva, 2015), but it implies a more holistic approach along the several touchpoints on the entire path to purchase. 
From the shopper marketing definition is noticeable that this kind of marketing approach implies recognizing that there are several other "moments of truth" besides the end consumption (Lamey et al., 2018). As Jones and Runyan (2016) state, when an individual is in shopping mode, such shopper purchase decision is often markedly different from decisions made whilst engaged in other stages of the traditional consumption process. So, the management of the several possible customer touchpoints must include the planning and shopping general moments, besides the mere end consumption.

There are several ways to categorize customer experience touchpoints along the path to purchase. For example, Lemon and Verhoef (2016) identify four types of touchpoints: brand-owned, partner-owned, customer-owned, and social/external/independent. All of them might be present in the prepurchase stage, purchase stage or postpurchase stage. Regardless of the discussion on designations and typologies, a representation of common general touchpoints along the path-topurchase is shown on Figure 1.

Figure 1. Path-to-purchase process and touchpoints

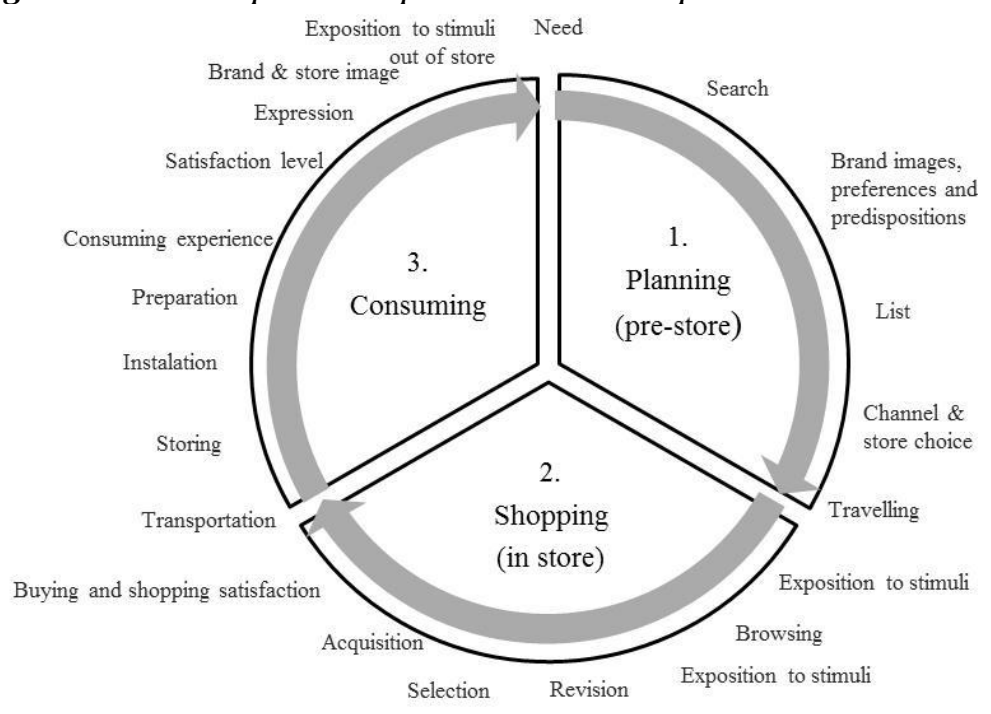

Source: Adapted from Retail Commission on Shopper Marketing (2010).

Discussing the theme of customer experience, Lemon and Verhoef (2016) mention that customers now interact with firms through a myriad touch points in multiple channels and media, making the understanding of customer experience and customer journey even more critical. Those authors mention as well that there is a solid foundation in academic and business literature that customer experience is created through the purchase journey, emphasize the importance of managing the different touch points in the customer journey. Turning this panorama even more complex, managers should keep in mind that the mind of the shopper is not neat, neither orderly nor totally conscious and logical (Soars, 2003). This means that the 
management of the customer touchpoints aims to provide a pathway to the purchase that can be triggered with in-store conscious and unconscious touchpoints actions. Furthermore, shopper marketing emphasizes that (Lamey et al., 2018, p. 433) "product success varies in function of the retail-shopper environment and allows for the distinct possibility that the effectiveness of marketing efforts can - and will vary based on the shopper retail context".

\subsection{Wine marketing touchpoints}

Following the already mentioned rationale of the path-to-purchase customer journey, the understanding of what drives wine choice is critical to successful wine marketing (McCutcheon et al., 2009). In fact, the analysis and understanding of consumers and shoppers in the wine industry is particularly important for marketing planning (Mora, 2016), due to the wine market specificities, namely the fragmented industry and myriad of brands (Vrontis et al., 2011).

Several of the studies found about retail wine purchasing have measured the intended purchasing as being influenced by personal characteristics or purchasing contexts (Lockshin \& Corsi, 2012). Another research stream addressed the influence of atmospherics in wine stores (North et al., 1999; Areni \& Kim, 1994; 1993). However, besides personal characteristics and store atmospherics, risk reducing strategies are particularly important in wine purchasing (Atkin \& Thach, 2012; Atkin et al., 2007; Mitchell \& Greatorex, 1989 and 1988). In fact, information search (i.e., learning about wine prior to buying choice, according to Olsen and Thach (2001)) might be expected to play an important role, because is a possible way of wine consumers to reduce the purchasing risk (Mitchell \& Greatorex, 1989). The importance of information search as a risk reducing strategy is explained by the several products, brands and alternatives available, as well as by the difficulty to assess knowledge of the product's attributes by visual inspection of the product (Chaney, 2000). In fact, wine is commonly perceived by consumers as a complicated product (Johnson \& Bruwer, 2007) and, when ordering wine in a restaurant, consumers perceive a high degree of risk or uncertainty (Bruwer et al., 2017; Lacey et al., 2009).

In a shopper marketing context, the customer touchpoints might act as important information sources, either acting consciously or subconsciously. These type of information sources can consist on experience, subjective knowledge, and objective knowledge on sources of information (Dodd et al., 2005). Specifically on wine purchasing information sources, several previous studies were found identifying the possible information sources, namely on the following sources: price (Gil \& Sánchez, 1997; Lockshin et al., 1993); cues on the wine package and label (Mueller et al., 2010; Verlegh \& Steenkamp, 1999); awards (Orth \& Krška, 2001); place/region and/or country of origin (Bruwer \& Buller, 2013; Johnson \& Bruwer, 2007; Orth et al., 2005; Felzensztein et al., 2004; Duhan et al., 1999; Gil \& Sánchez, 1997); online sources (Edwards, 1989); expert opinion by reading wine reviews and 
books (Chaney, 2000); grape vintage year (Mtimet \& Albisu, 2006; Ling \& Lockshin, 2003; Gil \& Sánchez, 1997); wine lists (Corsi et al., 2012); promotion and positioning of products inside the point of sale (Brodie \& Hollebeek, 2009); advice from salespersons/waiters and other persons (e.g. Parsons \& Thompson, 2009); samples and in-house display (Hall et al., 2004).

\subsection{Research objectives}

Connecting the conceptual relevance of customer touchpoints along the path to purchase and the specificities of wine purchasing, it is expected that customer touchpoints might have a positive influence on the attributes considered by shoppers on the purchasing moment.

Thereby, the present study aims to understand if that positive relation is verified in the context of on-trade wine customers - the simultaneous purchase and consumption in restaurants - in order to understand if the shopper marketing actions should be managed focusing efforts in a certain type of touchpoint or in several touchpoints. So, in this study, the hypothesis established is that a positive correlation exists between each wine choice attribute and each customer touchpoint.

\section{Research Methods}

\subsection{Procedures}

A quantitative empirical study was conducted with primary data collected among restaurant visitors. Recruiting and face-to-face interviewing were the data gathering techniques used, since face-to-face in interviews still deliver the most representative results in wine consumer research (Szolnokin \& Hoffmann, 2013). This research option is sustained by the fact that individuals can be asked directly about their purchasing behaviour (Lockshin et al., 2001; Bruwer et al., 2002).

Besides demographics, wine consuming frequency and wine knowledge level the variables measured with the questionnaire were grouped on (i) attributes on the wine choice (dependent variables) and (ii) consumer touchpoints along the path to purchase (independent variables). The items analysed on the attributes considered on wine choice were adapted from Cohen et al. (2009) and Hall et al. (2001), using a five-point importance-level options. The items considered on the costumer touchpoints group were adapted from Lacey et al. (2009), including instore and out of store touchpoints, and were measured with a five-point Likert response options. The items measured in each group were:

- Attributes on the wine choice: Wine colour, Type of grape, Wine region certification, Wine region, Price promotion, Price being low, Price being medium, Price being high, Wine formats available, Brand, Alcoholic grade, Wine age/year, Combination with the meal, wanted to try something different. 
- Costumer touchpoints along the path to purchase: Waiter recommendation, Previous positive experienced with the wine, Loyalty to the wine, Recommendation on the cart/menu, Influence of other people on the table, Suggestion of someone else not present, Previous information about the wine but had not tasted it yet, Something seen inside the restaurant awakened the interest, Previously seen ads, Read positive information on the internet, newspapers or magazines.

\subsection{Sample}

Primary data were collected in 15 restaurants, interviewing a sample of wine drinkers now of consumption in those restaurants. The sample consisted of 663 individuals, $51 \%$ of them male and $49 \%$ female.

Using Jonson and Bruwer (2007) options for the consumer self-reported wine consuming frequency, the wine consuming rates of this sample were: $13 \%$ once a day, $20 \%$ few times a week, $18 \%$ once a week, $16 \%$ once every two weeks, $15 \%$ once a month, $8 \%$ once every two months, and $10 \%$ consumes less frequently. Also using Jonson and Bruwer (2007) variables, the wine consumers' self-reported level knowledge about wines were: $12 \%$ said to be newt to wine, $34 \%$ know a little about wine, $44 \%$ somewhat knowledgeable about wine, 9\% Very knowledgeable about wine $9 \%$, and $1 \%$ expert or professional.

\section{Findings}

As a previous step to compute the correlations of wine choice attributes with wine costumer touchpoints, the perceived importance of each wine attribute on the purchase choice was computed, calculating the mean importance and standard deviation for each wine attribute, presented in Table 1. The wine attributes evidencing a mean importance higher than 3,5 (ie threshold higher than neutral) were: wine colour, combination of the wine with the specific meal, terroir/region of origin, brand, and the having a formally certified wine. Among these, the wine colour and the combination of the wine with the food were clearly the most important ones.

Another preliminary step made was the analysis of the costumer touchpoints' general influence, calculating the mean and standard deviation for each touchpoint (Table 2). Touchpoint "OT1 Already experienced the wine before and liked it" was clearly the most relevant one.

Table 3 shows the correlations of wine choice attributes with each touchpoint (the same Table 3 is simplified in appendix A showing only the positive significant correlations found). Based on the results of Table 3, the hierarchy of statistically significant positive correlations of wine attributes and touchpoints are shown in Table 4 . 
Table 1. Wine choice attributes importance

\begin{tabular}{l|l|l}
\hline Attributes & mean & st.dev. \\
\hline A1 Wine color (red, white, etc) & 4,21 & 0,84 \\
A2 Type of grape & 3,19 & 1,10 \\
A3 The region is certified & 3,61 & 1,04 \\
A4 Wine region & 3,86 & 0,99 \\
A5 Price promotion & 3,22 & 1,21 \\
A6 Price is low & 3,01 & 1,21 \\
A7 Price is medium & 2,91 & 1,05 \\
A8 Price is high & 2,78 & 1,18 \\
A9 The wine is available in various formats & 3,01 & 1,19 \\
A10 Brand & 3,82 & 1,00 \\
A11 Alcoholic grade & 3,11 & 1,19 \\
A12 Wine age/year & 3,38 & 1,20 \\
A13 Combination with the meal/food & 4,10 & 1,02 \\
A14 Wanted to try something different & 2,93 & 1,30
\end{tabular}

Table 2. Customer touchpoints' relevance

\begin{tabular}{|c|c|c|c|c|}
\hline Type & & Touchpoint & mean & st.dev. \\
\hline Instore & & IT1 Waiter recommendation & 3,10 & 1,29 \\
\hline $\begin{array}{l}\text { Out } \\
\text { store }\end{array}$ & of & OT1 Already experienced the wine before and liked it & 3,81 & 1,14 \\
\hline $\begin{array}{l}\text { Out } \\
\text { store }\end{array}$ & of & $\begin{array}{l}\text { OT2 The wine is one of the three wines the shopper is } \\
\text { more loyal to }\end{array}$ & 3,00 & 1,37 \\
\hline Instore & & IT2 Recommendation of the restaurant menu/cart & 2,98 & 1,36 \\
\hline Instore & & IT3 Suggestion of someone else on the table & 2,67 & 1,31 \\
\hline $\begin{array}{l}\text { Out } \\
\text { store }\end{array}$ & of & OT3 Suggestion of someone else not present & 2,19 & 1,06 \\
\hline $\begin{array}{l}\text { Out } \\
\text { store }\end{array}$ & of & $\begin{array}{l}\text { OT4 Had information about the wine but had not tasted it } \\
\text { yet }\end{array}$ & 2,84 & 1,3 \\
\hline Instore & & $\begin{array}{l}\text { IT4 Saw something in the restaurant that awaken the } \\
\text { interest }\end{array}$ & 2,70 & 1,20 \\
\hline $\begin{array}{l}\text { Out } \\
\text { store }\end{array}$ & of & OT5 Had already seen ads about the wine and was curious & 2,69 & 1,28 \\
\hline $\begin{array}{l}\text { Out } \\
\text { store }\end{array}$ & of & $\begin{array}{l}\text { OT6 Had read positive information about the wine on the } \\
\text { internet, newspapers or magazines }\end{array}$ & 2,66 & 1,28 \\
\hline
\end{tabular}

It is noticeable that OT1 (Already experienced the wine before and liked it) is the most important customer touchpoint out of thirteen wine attributes with positive correlations. 
Touchpoints IT1 (Waiter recommendation) and OT4 (Had information about the wine but had not tasted it yet) are also important, since OT4 is significant in 8 wine attributes, and IT1 is significant in 7 attributes. Just like OT1, touchpoints OT4 and IT1 seem to be reliable information sources to reduce the risk decision of choosing the appropriate wine.

Restricting the analysis only to the most important wine choice attributes (ie, the wine choice attributes with mean importance higher than 3,5), the results in Table 4 show that "Wine colour", "Wine region" and "Certified wine region" were positively influenced by just one touchpoint - OT1, reinforcing the previously mentioned deduction of OT1's relevance.

However, the attribute "Brand" was influenced by more touchpoints besides OT1, namely OT2 (The wine is one of the three wines the shopper is more loyal to) and OT5 (Had already seen ads about the wine and was curious). This result highlights the relevance of an integrated management of several touchpoints along the entire path-to-purchase, instead of acting on only one. Furthermore, in Table 4 is noticeable that every touchpoint has at least two positive correlations with wine attributes - the minimum is two positive correlations in OT3, and the maximum is eight positive correlations in IT2.

\section{Conclusions}

In the context of shopper marketing, our study aimed to understand if the attributes considered by wine customers in restaurants are influenced by a touchpoint. This is particularly important to understand if shopper marketing actions should focus efforts in a certain type of touchpoint.

The results pointed to the high relevance of the touchpoint related to previous wine consumption experience by the customer. This customer touchpoint was the one with the highest mean importance and had six positive significant correlations with wine choice attributes. As a managerial implication, is important that wine producers must be capable to design and produce wines that satisfy the consumer, in order to repeat consumption decisions. This seems to be particularly important in highly fragmented markets, like the wine industry, characterized by a myriad of product of brands available for customers to choose from.

Some wine choice attributes were influenced by more than one touchpoint. The attribute "wine brand" is particularly relevant in this context, because it was one of the most important attributes and was positively influenced by three touchpoints: previous consumption experience; shopper loyalty to the product; and having already seen ads about the wine and was curious. This fact of attributes being influenced by several touchpoints suggests that managers should not aim to simplify the shopper marketing management by acting only on few touchpoints. By the contrary, brands should design shopping marketing activities along the entire path- 
to-purchase, covering all the touchpoints. So, wine companies could allocate more resources and focus in certain touchpoints but should not neglect the other ones.

Table 3. Correlations of wine choice attributes attributes vs customer touchpoints

\begin{tabular}{|c|c|c|c|c|c|c|c|c|c|}
\hline Attribute & IT1 & OT1 & OT2 & IT2 & IT3 & OT3 & OT4 & IT4 & OT5 \\
\hline \multirow[t]{2}{*}{ A1 } &,$- 118^{* * *}$ &, $063^{*}$ &,$- 075^{* *}$ &,$- 172^{* * * *}$ &,$- 180^{* * * *}$ &,$- 334^{* * *}$ &,$- 116^{* * *}$ &,$- 182^{* * *}$ &,$- 094^{* *}$ \\
\hline &, 002 &, 057 &, 043 &, 000 &, 000 &, 000 &, 002 &, 000 &, 010 \\
\hline \multirow[t]{2}{*}{$\mathrm{A} 2$} &,- 050 &, 038 &, 035 &, $081^{* *}$ &,- 058 &,$- 134^{* * *}$ &, $110^{* * *}$ &, $094^{* *}$ &, 054 \\
\hline &, 123 &, 190 &, 227 &, 045 &, 130 &, 005 &, 005 &, 015 &, 107 \\
\hline \multirow[t]{2}{*}{$\mathrm{A} 3$} &,$- 159^{* * *}$ &, $099^{* *}$ &,- 025 &,- 029 &,$- 261^{* * *}$ &,$- 262^{* * *}$ &, 034 &,- 026 &, 036 \\
\hline &, 000 &, 018 &, 321 &, 291 &, 000 &, 000 &, 238 &, 289 &, 226 \\
\hline \multirow[t]{2}{*}{ A4 } &,$- 156^{* * *}$ &, $101^{* *}$ &,$- 080^{* *}$ &,- 072 &,$- 118^{* * *}$ &,$- 232^{* * *}$ &,$- 079^{* *}$ &,$- 118^{* * *}$ &,$- 104^{* *}$ \\
\hline &, 001 &, 017 &, 049 &, 066 &, 007 &, 000 &, 048 &, 007 &, 016 \\
\hline \multirow[t]{2}{*}{ A5 } &, $197^{* * * *}$ &, 045 &, 009 &, $171^{* * *}$ &, $135^{* * *}$ &, 056 &, $107^{* * *}$ &, $102^{* * * *}$ &, 041 \\
\hline &, 000 &, 136 &, 419 &, 000 &, 002 &, 116 &, 004 &, 006 &, 158 \\
\hline \multirow[t]{2}{*}{ A6 } & $139^{* * *}$ &, 011 &,- 015 &, $162^{* * *}$ & $108^{* *}$ &, 014 &, 006 &, 051 &,$- 083^{* *}$ \\
\hline &, 001 &, 404 &, 369 &, 000 &, 011 &, 384 &, 445 &, 124 &, 029 \\
\hline \multirow[t]{2}{*}{ A7 } &, $071^{*}$ &, $061^{*}$ &, 026 &, 052 &, 047 &,- 023 &, 002 &, 013 &,- 028 \\
\hline &, 051 &, 081 &, 280 &, 117 &, 161 &, 310 &, 481 &, 387 &, 260 \\
\hline \multirow[t]{2}{*}{ A8 } & $107^{* * *}$ &, 007 &, 043 &, $117^{* * *}$ &, $159^{* * *}$ &, 049 &, $136^{* * * *}$ &, $079^{* *}$ &, $087^{* * *}$ \\
\hline &, 007 &, 434 &, 167 &, 004 &, 000 &, 149 &, 001 &, 036 &, 025 \\
\hline \multirow[t]{2}{*}{ A9 } &, $139^{* * * *}$ &, 021 &,$- 075^{* *}$ &, $126^{* * *}$ &,- 044 &,- 054 &, $071^{* *}$ &, $111^{* * *}$ &, 022 \\
\hline &, 000 &, 300 &, 044 &, 002 &, 178 &, 127 &, 040 &, 003 &, 292 \\
\hline \multirow[t]{2}{*}{ A10 } &, 027 &, $152^{* * *}$ &, $141^{* * *}$ &, 049 &, 059 &,- 053 &,- 042 &,- 026 &, $073^{* * *}$ \\
\hline &, 250 &, 000 &, 001 &, 129 &, 102 &, 129 &, 149 &, 261 &, 035 \\
\hline \multirow[t]{2}{*}{ A11 } &, $145^{* * *}$ &, $075^{* *}$ &, $153^{* * * *}$ &, $122^{* * *}$ &, $150^{* * *}$ &, $075^{*}$ &, $166^{* * * *}$ &, $164^{* * *}$ &, $120^{* * * *}$ \\
\hline &, 000 &, 031 &, 000 &, 002 &, 001 &, 054 &, 000 &, 000 &, 001 \\
\hline \multirow[t]{2}{*}{ A12 } &, 017 &, 021 &, $080^{* *}$ &, $095^{* *}$ &, 043 &,- 039 &, $070^{* *}$ &, $073^{* *}$ &, $127^{* * * *}$ \\
\hline &, 332 &, 303 &, 034 &, 015 &, 180 &, 205 &, 041 &, 035 &, 001 \\
\hline \multirow[t]{2}{*}{ A13 } &,$- 230^{* * * *}$ &,- 017 &,$- 142^{* * *}$ &,$- 157^{* * * *}$ &,$- 159^{* * * *}$ &,$- 245^{* * *}$ &,$- 165^{* * * *}$ &,$- 263^{* * * *}$ &,$- 138^{* * *}$ \\
\hline &, 000 &, 348 &, 001 &, 000 &, 000 &, 000 &, 000 &, 000 &, 001 \\
\hline \multirow[t]{2}{*}{ A14 } &, $429^{* * *}$ &,$- 154^{* * *}$ &,- 022 &, $400^{* * *}$ &, $373^{* * * *}$ &, $335^{* * *}$ &, $616^{* * * *}$ &, $497^{* * *}$ &, $362^{* * * *}$ \\
\hline &, 000 &, 000 &, 332 &, 000 &, 000 &, 000 &, 000 &, 000 &, 000 \\
\hline
\end{tabular}

Notes: Spearman correlation 1-tailed, * Significant at .10 level, ** Significant at .05 level, *** Significant at .01 level.

This research has limitations that can point to further research directions. The sample poses research limitations due to having studied the individuals' opinions and perceptions in a certain moment and specific place/restaurant. Therefore, is recommended to enlarge the study to different samples, in order to examine the possibility of results' generalization. The number of wine choice attributes was not 
exhaustive, so that the questionnaire and interviews were not too long. The same research option was made regarding the customer touchpoints presented. Both facts could be minimized in future researches by using more detailed questionnaires.

Table 4. Hierarchy of positive significant correlations of choice attributes vs touchpoints

\begin{tabular}{l|l}
\hline Attributes* & Touchpoint \\
\hline A1 Wine color & OT1 \\
A13 Combination with the meal/food & None \\
A4 Wine region & OT1 \\
A10 Brand & OT1 $>$ OT2 > OT5 \\
A3 The region is certified & OT1 \\
A12 Wine age/year & OT5 $>$ OT6 $>$ IT2 $>$ OT2 > IT4 > OT4 \\
A5 Price promotion & IT1 $>$ IT2 $>$ IT3 $>$ OT4 $>$ IT4 \\
A2 Type of grape & OT4> IT4 $>$ IT2 $>$ OT6 \\
A11 Alcoholic grade & OT4 $>$ IT4 > IT2 >IT1 > IT2 > OT5 > OT6> \\
A9 The wine is available in various & IT1 $>$ IT2 > IT4 >OT4 \\
A6 Price is low & IT2 $>$ IT1 $>$ IT3 \\
A14 Wanted to try something different & OT4> IT4 $>$ IT1 > IT2 > IT3 > OT5 > OT6 > OT3 \\
A7 Price is medium & IT1 $>$ OT1 \\
A8 Price is high & IT3 $>$ OT4 $>$ IT2 > IT1 > OT5 > IT4 \\
\hline
\end{tabular}

Note: *Wine choice attributes ordered by their mean importance, from highest to lowest.

In a global manner, we conclude that, for restaurants wine costumers, touchpoints should be managed along the entire path-to-purchase, but efforts and resources might be focused on a small number of more effective touchpoints. Albeit, the effectiveness of marketing efforts will probably vary in other sectors or retail contexts, opening research avenues to future studies.

\section{References:}

Ailawadi, K.L., Beauchamp, J.P., Donthu, N., Gauri, D.K. \& Shankar, V. 2009. Communication and promotion decisions in retailing: a review and directions for future research. Journal of Retailing, 85(1), 42-55.

Areni, C.S. \& Kim, D. 1993. The influence of background music on shopping behavior: classical versus top-forty music in a wine store. Advances in consumer research, 20(1), 336-340.

Areni, C.S. \& Kim, D. 1994. The influence of in-store lighting on consumers' examination of merchandise in a wine store. International journal of research in marketing, 11(2), 117-125.

Atkin, T. Nowak, L. \& Garcia, R. 2007. Women wine consumers: information search and retailing implications. International Journal of Wine Business Research, 19(4), 327339. 
Atkin, T. \& Thach, L. 2012. Millennial wine consumers: risk perception and information search. Wine Economics and Policy, 1(1), 54-62.

Barber, N. 2012. Consumers' intention to purchase environmentally friendly wines: a segmentation approach. International Journal of Hospitality and Tourism Administration, 13, 26-47.

Bogetić, Z. \& Stojković, D. 2015. Systematic Shopper Marketing for Sustainable Competitive Advantage. Trade Perspectives, 134-150.

Brodie, R., Hollebeek, L.D. 2009. Wine service marketing, value co-creation and involvement: research issues. International Journal of Wine Business Research, Vol. 21(4), 330-252.

Bruwer, J. \& Buller, C. 2013. Product involvement, brand loyalty, and country-of-origin brand preferences of Japanese wine consumers. Journal of wine research, 24(1), 3858.

Bruwer, J., Arias, A.P.P. \& Cohen, J. 2017. Restaurants and the single-serve wine by-theglass conundrum: Risk perception and reduction effects. International Journal of Hospitality Management, 62, 43-52.

Casini, L, Corsi, A., Goodman, S. 2009. Consumer preferences of wine in Italy applying best-worst scaling. International Journal of Wine Business Research, 21, 64-78.

Chaney, I.M. 2000. External search effort for wine. International journal of wine marketing, 12(2), 5-21.

Cohen, E., d'Hauteville, F. \& Sirieix, L. 2009. A cross-cultural comparison of choice criteria for wine in restaurants. International Journal of Wine Business Research, 21(1), 5063.

Corsi, A.M. Mueller, S. \& Lockshin, L. 2012. Let's see what they have what consumers look for in a restaurant wine list. Cornell Hospitality Quarterly, 53(2), 110-121.

Dodd, T.H., Laverie, D.A., Wilcox, J.F. \& Duhan, D.F. 2005. Differential effects of experience, subjective knowledge, and objective knowledge on sources of information used in consumer wine purchasing. Journal of Hospitality \& Tourism Research, 29(1), 3-19.

Duhan, D., Kiecker, P., Areni, C. \& Guerrero, C. 1999. Origin information and retail sales of wine. International Journal of Wine Marketing, 11 (3), 44-58.

Edwards, F. 1989. The marketing of wine from small wineries: Managing the intangibles. International Journal of Wine Marketing, 1(1), 14-17.

Felzensztein, C., Hibbert, S. \& Vong, G. 2004. Is the country of origin the fifth element in the marketing mix of imported wine? A critical review of the literature. Journal of Food Products Marketing, 10(4), 73-84.

Gavilan, D., Avello, M. \& Abril, C. 2014. Shopper Marketing: A New Challenge for Spanish Community Pharmacies. Research in Social and Administrative Pharmacy, Vol. 10, No. 6, e125-e136.

Gil, J.M. \& Sánchez, M. 1997. Consumer preferences for wine attributes: a conjoint approach. British Food Journal, 99(1), 3-11.

Hall, J., Lockshin, L. \& Barry O'Mahony, G. 2001. Exploring the links between wine choice and dining occasions: Factors of influence. International journal of wine marketing, 13(1), 36-53.

Hall, J. Binney, W. \& O'Mahoney, G. 2004. Age related motivational segmentation of wine consumption in a hospitality setting. International Journal of Wine Marketing, 16 (3), 29-43.

Handley, I. \& Lockshin, L. 1997. Wine purchasing in Singapore: a supermarket observation approach. International Journal of Wine Marketing, 9(2), 70-82. 
Hildebrandt, S. 2012. High hopes for on-premise. Beverage Industry, 10(4), 48-50.

Hollebeek, L., Jaeger, S., Brodie, R. \& Balemi, A. 2007. The influence of involvement on purchase intention for new world wine. Food Quality and Preference, 18, 1033-1049.

Jaeger, S.R., Danaher, P.J. \& Brodie, R.J. 2010. Consumption decisions made in restaurants: The case of wine selection. Food quality and preference, 21(4), 439-442.

Johnson, R. \& Bruwer, J. 2007. Regional brand image and perceived wine quality: the consumer perspective. International Journal of Wine Business Research, 19(4), 276297.

Jones, R.P. \& C. Runyan, R. 2016. Conceptualizing a path-to-purchase framework and exploring its role in shopper segmentation. International Journal of Retail \& Distribution Management, 44(8), 776-798.

Lacey, S., Bruwer, J. \& Li, E. 2009. The role of perceived risk in wine purchase decisions in restaurants. International Journal of Wine Business Research, 21(2), 99-117.

Lamey, L., Deleersnyder, B., Steenkamp, J.B.E. \& Dekimpe, M.G. 2018. New product success in the consumer-packaged goods industry: A shopper marketing approach. International Journal of Research in Marketing, 35, 432-452.

Lee, L., Inman, J., Argo, J., Bottger, T., Dholakia, U., Gilbride, T., van Ittersum, K., Kahn, B., Kalra, A., Lehmann, D., McAlister, L., Shankar, V. \& Tsai, C.I. 2017. From Browsing to Buying and Beyond: The Needs-Adaptive Shopper Journey Model. Rotman School of Management Working Paper No. 3093999; University of Alberta School of Business Research Paper No. 2017-2712.

Lemon, K.N. \& Verhoef, P.C. 2016. Understanding customer experience throughout the customer journey. Journal of Marketing, 80(6), 69-96.

Ling, B.H. \& Lockshin, L. 2003. Components of wine prices for Australian wine: how winery reputation, wine quality, region, vintage, and winery size contribute to the price of varietal wines. Australasian Marketing Journal, 11(3), 19-32.

Lockshin, L. \& Corsi, A. 2012. Consumer behaviour for wine 2.0: A review since 2003 and future directions. Wine Economics and Policy 1, 2-23.

Lockshin, L. \& Kahrimanis, P. 1998. Consumer evaluation of retail wine stores. Journal of Wine Research, 9(3), 173-184.

Lockshin, L., Knott. D. 2009. Boozing or branding? Measuring the effects of free wine tastings at wine shops. International Journal of Wine Business Research, 21, 312-324.

Lockshin, L. \& Timothy Rhodus, W. 1993. The effect of price and oak flavor on perceived wine quality. International Journal of Wine Marketing, 5(2/3), 13-25.

McCutcheon, E., Bruwer, J. \& Li, E. 2009. Region of origin and its importance among choice factors in the wine-buying decision making of consumers. International Journal of Wine Business Research, 21(3), 212-234.

Mitchell, V.W. \& Greatorex, M. 1988. Consumer risk perception in the UK wine market. European Journal of Marketing, 22(9), 5-15.

Mitchell, V.W. \& Greatorex, M. 1989. Risk reducing strategies used in the purchase of wine in the UK. International Journal of Wine Marketing, 1(2), 31-46.

Mora, P. 2016. When the E-Shopper Meets the Wine Industry. In Wine Positioning (pp. 8191), Springer International Publishing.

Mtimet, N. \& Albisu, L.M. 2006. Spanish wine consumer behavior: A choice experiment approach. Agribusiness 22(3), 343-362.

Mueller, S., Lockshin, L., Saltman, Y., Blanford, J. 2010a. Message on a bottle: the relative influence of wine back label information on wine choice. Food Quality and Preference, 21, 22-32. 
Mueller, S., Osidacz, P., Francis, I., Lockshin, L. 2010b. Combining discrete choice and informed sensory testing in a two-stage process can it predict wine market share? Food Quality and Preference, 21, 741-754.

North, A.C., Hargreaves, D.J. \& McKendrick, J. (1999). The influence of in-store music on wine selections. Journal of Applied psychology, 84(2), 271.

Olsen, J., Thach, L. 2001. Consumer behavior regarding wine consumption: a conceptual framework. Australian and New Zealand Wine Business Journal-Special Marketing Addition, 16 (6), 123-129.

Orth, U.R., Bourrain, A. 2005. Ambient scent and consumer exploratory behaviour: a causal analysis. Journal of Wine Research, 16, 137-150.

Orth, U.R. \& Krška, P. 2001. Quality signals in wine marketing: the role of exhibition awards. The International Food and Agribusiness Management Review, 4(4), 385397.

Orth, U.R., McGarry, W.M. \& Dodd, T.H. 2005. Dimensions of wine region equity and their impact on consumer preferences. Journal of Product \& Brand Management, 14(2), 8897.

Parsons, A.G. \& Thompson, A.M. 2009. Wine recommendations: who do I believe? British food journal, 111(9), 1003-1015.

Pinto, G.L., Pinto, G.L., Dell'Era, C., Dell'Era, C., Verganti, R., Verganti, R. \& Bellini, E. 2017. Innovation strategies in retail services: solutions, experiences and meanings. European Journal of Innovation Management, 20(2), 190-209.

Pomarici, E., Boccia, F. \& Catapano, D. 2012. The wine distribution systems over the world: An explorative survey. New Medit, 11(4), 23-32.

Preszler, T. \& Schmit, T.M. 2009. Factors affecting wine purchase decisions and presence of New York wines in upscale New York City restaurants. Journal of food distribution research, 40(3), 16-30.

Quinton, S. Harridge-March, S. 2008. Trust and online wine purchasing: insights into UK consumer behavior. International Journal of Wine Business Research, 20, 68-85.

Retail Commission on Shopper Marketing 2010. Shopper Marketing Best Practices: A Collaborative Model for Retailers and Manufacturers. In-Store Marketing Institute.

Ritchie, C. Elliott, G. Flynn, M. 2010. Buying wine on promotion is trading-up in UK supermarkets: a case study in Wales and Northern Ireland. International Journal of Wine Business Research, 22, 102-121.

Shankar, V., Inman, J., Mantrala, M., Kelley, E. \& Rizley, R. 2011. Innovations in Shopper Marketing: Current Insights and Future Research Issues. Journal of Retailing, 87S (1), S29-S42.

Szolnokin, G. \& Hoffmann, D. (2013). Online, face-to-face and telephone surveys Comparing different sampling methods in wine consumer research. Wine Economics and Policy, 2, 57-66.

Stening, S. \& Lockshin, L. 2001. A comparison of on-line and in-store customers in the wine retail sector. Special Wine Marketing Supplement to the Australian and New Zealand Wine Industry Journal, 16 (6), 138-144.

Verlegh, W. Steenkamp, J. 1999. A review and meta-analysis of country-of-origin research. Journal of Economic Psychology, 20, 521-546.

Vrontis, D., Thrassou, A. \& Czinkota, M.R. 2011. Wine marketing: A framework for consumer-centred planning. The Journal of Brand Management, 18(4-5), 245-263.

Ziliani, C. \& Ieva, M. 2015. Retail shopper marketing: The future of promotional flyers. International Journal of Retail \& Distribution Management, 43(6), 488-502. 
The Relevance of Shopper Marketing Touchpoints: An Empirical Study on Wine Choice in Restaurants

48

Appendix A. Positive correlations of attributes vs touchpoints

Touchpoint

\begin{tabular}{|c|c|c|c|c|c|c|c|c|c|c|}
\hline Attribu & IT1 & OT1 & OT2 & IT2 & IT3 & OT3 & OT4 & IT4 & OT5 & OT6 \\
\hline A1 & &, $063^{*}$ & & & & & & & & \\
\hline A2 & & & &, $081^{* *}$ & & &, $110^{* * *}$ &, $094^{* *}$ & &, $075^{* *}$ \\
\hline A3 & &, $099^{* *}$ & & & & & & & & \\
\hline A4 & &, $101^{* *}$ & & & & & & & & \\
\hline A5 &, $197^{* *}$ & & &, $171^{* * * *}$ &, $135^{* * * *}$ & &, $107^{* * *}$ & $102^{* * * *}$ & & \\
\hline A6 & $139^{* * *}$ & & &, $162^{* * * *}$ &, $108^{* *}$ & & & & & \\
\hline A7 &, $071^{*}$ &, $061^{*}$ & & & & & & & & \\
\hline A8 & $107^{* *}$ & & &, $117^{* * * *}$ & $159^{* * * *}$ & & $136^{* * *}$ &, $079^{* *}$ &, $087^{* *}$ & \\
\hline A9 & $139^{* *}$ & & & $126^{* * * *}$ & & &, $071^{* *}$ &, $111^{* * * *}$ & & \\
\hline A10 & & $152^{* * * *}$ & $141^{* * * *}$ & & & & & &, $073^{* *}$ & \\
\hline A11 & $145^{* *}$ &, $075^{* *}$ & $153^{* * *}$ &, $122^{* * * *}$ &, $150^{* * * *}$ &, $075^{*}$ &, $166^{* * *}$ &, $164^{* * * *}$ &, $120^{* * * *}$ &, $119^{* * * *}$ \\
\hline A12 & & &, $080^{* * *}$ &, $095^{* *}$ & & &, $070^{* *}$ &, $073^{* * *}$ &, $127^{* * *}$ &, $115^{* * * *}$ \\
\hline A13 & & & & & & & & & & \\
\hline A14 &, $429^{* *}$ & & &, $400^{* * * *}$ &, $373^{* * * *}$ &, $335^{* * * *}$ &, $616^{* * *}$ &, $497^{* * * *}$ &, $362^{* * *}$ &, $337^{* * * *}$ \\
\hline
\end{tabular}

Note: Spearman correlation 1-tailed, *Significant at .10;**Significant at .05; ***Significant at .01 